


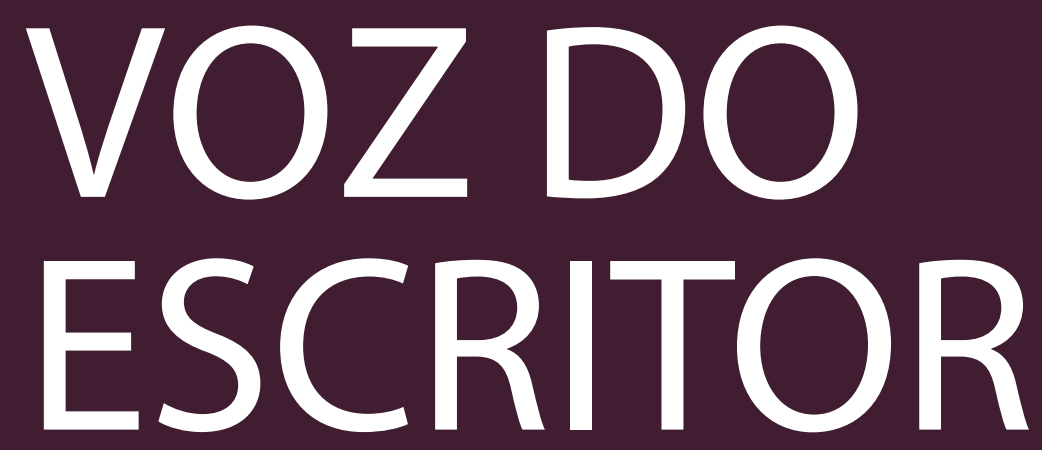




\section{POEMAS DE ANGÉLICA FREITAS}

- ANGÉLICA FREITAS 1

porque uma mulher boa

é uma mulher limpa

e se ela é uma mulher limpa

ela é uma mulher boa

há milhões, milhões de anos

pôs-se sobre duas patas

a mulher era braba e suja

braba e suja e ladrava

porque uma mulher braba

não é uma mulher boa

e uma mulher boa

é uma mulher limpa

há milhões, milhões de anos

pôs-se sobre duas patas

não ladra mais, é mansa

é mansa e boa e limpa

uma mulher muito feia

era extremamente limpa

e tinha uma irmã menos feia

que era mais ou menos limpa

e ainda uma prima

[1] Poemas extraídos de Freitas, Angélica. Um útero é do tamanho de um punho. São Paulo: Companhia das Letras, 2017. 
incrivelmente bonita que mantinha tão somente as partes essenciais limpas que eram o cabelo e o sexo

mantinha o cabelo e o sexo extremamente limpos com um xampu feito no texas por mexicanos aburridos

mas a heroína deste poema era uma mulher muito feia extremamente limpa que levou por muitos anos uma vida sem eventos uma mulher insanamente bonita um dia vai ganhar um automóvel com certeza vai ganhar um automóvel e muitas flores quantas forem necessárias mais que as feias, as doentes e as secretárias juntas já uma mulher estranhamente bonita pode ganhar flores e também pode ganhar um automóvel

mas um dia vai com certeza vai precisar vendê-lo

\section{MULHER DE RESPEITO}

diz-me com quem te deitas

angélica freitas 


\section{ÍTACA}

se quiser empreender viagem a ítaca

ligue antes

porque parece que tudo em ítaca

está lotado

os bares os restaurantes

os hotéis baratos

os hotéis caros

já não se pode viajar sem reservas

ao mar jônico

e mesmo a viagem

de dez horas parece dez anos

escalas no egito?

nem pensar

e os freeshops estão cheios

de cheiros que você pode comprar

com cartão de crédito.

toda a vida você quis

visitar a grécia

era um sonho de infância

concebido na adultidade

itália, frança: adultério

(coisa de adultos?

não escuto resposta)

bem se quiser vá a ítaca

peça a um primo

que lhe empreste euros e vá a ítaca

é mais barato ir à ilha de comandatuba

mas dizem que o azul do mar

não é igual.

aproveite para mandar e-mails

dos cybercafés locais

quem manda postais?

mande fotos digitais

torre no sol

leve hipoglós

em ítaca compreenderá

para que serve

a hipoglós. I 
